\title{
Growth on Alpha-Ketoglutarate Increases Oxidative Stress Resistance in the Yeast Saccharomyces cerevisiae
}

\author{
Maria Bayliak, Nadia Burdyliuk, and Volodymyr Lushchak \\ Department of Biochemistry and Biotechnology, Vasyl Stefanyk Precarpathian National University, \\ 57 Shevchenko Str., Ivano-Frankivsk 76018, Ukraine \\ Correspondence should be addressed to Maria Bayliak; bayliak@ukr.net
}

Received 25 July 2016; Accepted 18 December 2016; Published 5 January 2017

Academic Editor: Hugh W. Morgan

Copyright (C) 2017 Maria Bayliak et al. This is an open access article distributed under the Creative Commons Attribution License, which permits unrestricted use, distribution, and reproduction in any medium, provided the original work is properly cited.

Alpha-ketoglutarate $(\mathrm{AKG})$ is an important intermediate in cell metabolism, linking anabolic and catabolic processes. The effect of exogenous AKG on stress resistance in S. cerevisiae cells was studied. The growth on AKG increased resistance of yeast cells to stresses, but the effects depended on AKG concentration and type of stressor. Wild-type yeast cells grown on AKG were more resistant to hydrogen peroxide, menadione, and transition metal ions $\left(\mathrm{Fe}^{2+}\right.$ and $\left.\mathrm{Cu}^{2+}\right)$ but not to ethanol and heat stress as compared with control ones. Deficiency in SODs or catalases abolished stress-protective effects of AKG. AKG-supplemented growth led to higher values of total metabolic activity, level of low-molecular mass thiols, and activities of catalase and glutathione reductase in wild-type cells compared with the control. The results suggest that exogenous AKG may enhance cell metabolism leading to induction of mild oxidative stress. It turn, it results in activation of antioxidant system that increases resistance of S. cerevisiae cells to $\mathrm{H}_{2} \mathrm{O}_{2}$ and other stresses. The presence of genes encoding SODs or catalases is required for the expression of protective effects of AKG.

\section{Introduction}

In all aerobic organisms, reactive oxygen species (ROS) are continuously generated as side products of cellular metabolism. These species, namely, superoxide anion radical $\left(\mathrm{O}_{2}{ }^{--}\right)$, hydrogen peroxide $\left(\mathrm{H}_{2} \mathrm{O}_{2}\right)$, and hydroxyl radical $\left(\mathrm{HO}^{*}\right)$, are potentially dangerous due to their high reactivity and capability to interact virtually with all cellular components including proteins, lipids, nucleic acids, and carbohydrates. For defense against ROS, cells contain antioxidant enzymes such as superoxide dismutase (SOD), catalase, and several peroxidases, as well as thiol-containing antioxidants like glutathione and thioredoxin. Under some circumstances, the balance between ROS generation and their elimination is disturbed leading to enhanced ROS level called "oxidative stress". This imbalance can result from exposure to diverse environmental stress conditions such as the presence of oxidants, heat shock, ethanol, and metal ions. Oxidative stress development plays a pivotal role in aging and numerous diseases, including cancer and cardiovascular and neurodegenerative diseases $[1,2]$. Therefore, there has been a growing interest in low-molecular mass natural antioxidant molecules that prevent and alleviate the effects of oxidative stress [3-5].

Many studies report on the antioxidant properties of alpha-ketoglutarate (AKG) which is an important intermediate in the Krebs cycle. Primarily, protective effects of AKG were established in vitro systems. In particular, AKG prevented $\mathrm{H}_{2} \mathrm{O}_{2}$-induced hemolysis of human erythrocytes [6] and iron-induced lipid peroxidation in rat brain in vitro [7]. An antioxidant action of AKG was proposed to be mediated through nonenzymatic interaction of AKG with $\mathrm{H}_{2} \mathrm{O}_{2}$ with formation of succinate, carbon dioxide, and water $[6,8]$. Subsequently, the antioxidant mode of AKG was found to be involved in its protective effects against different toxicants. According to this, dietary AKG prevented the increase in the levels of oxidative stress markers in rats under chronic ethanol administration [9] and cyanide treatment [10] and in Drosophila melanogaster flies exposed to sodium nitroprusside [11].

In addition to direct antioxidant function, recent studies show that AKG increased the capacity of endogenous antioxidant system [12, 13]. Experiments with human erythrocytes 
demonstrated that AKG could serve as glutamate source for the synthesis of glutathione, an important low-molecular mass thiol antioxidant [14]. This ketoacid also stabilized redox homeostasis in aged mice via stimulation of antioxidant defense [12]. Moreover, AKG supplement was found to increase lifespan in nematode Caenorhabditis elegans [15] and this effect was accompanied by concomitant increase in ROS generation. The prooxidant effect of AKG seems to be due to the altered intensity of the Krebs cycle in which AKG is preferentially metabolized $[16,17]$. A small increase in ROS level may be beneficial for an organism due to the induction of mild oxidative stress which results in stimulation of defense systems with increasing adaptive capacity $[1,18-$ 20]. In line with this, the activation of antioxidant defense and the enhanced cold tolerance were found in D. melanogaster flies grown on AKG-supplemented food [13].

Previously we showed that AKG increased resistance of budding yeast $S$. cerevisiae to hydrogen peroxide in combined treatment [8]. In this work, we aimed at studying an adaptive potential of $S$. cerevisiae cells grown in the medium supplemented with AKG. For this, control and AKG-grown cells from exponentially growing cultures were transferred to a new medium followed by treatment with different stressors, and yeast survival was monitored. We investigated also if the protective effects of AKG were associated with the induction of endogenous antioxidant defense. Yeast mutants defective in certain components of antioxidant system were used to reveal the key endogenous antioxidants required for realization of the effects of AKG.

\section{Materials and Methods}

2.1. Chemicals. Phenylmethylsulfonyl fluoride (PMSF), ethylenediaminetetraacetic acid (EDTA), 2,4-dinitrophenylhydrazine (DNPH), 5,5'-dithiobis-2-nitrobenzoic acid (DTNB), 2,3,5-triphenyl tetrazolium chloride (TTC), oxidized glutathione (GSSG), $\mathrm{NADPH}, \mathrm{FeSO}_{4} \times 7 \mathrm{H}_{2} \mathrm{O}$, and menadione were obtained from Sigma-Aldrich Corporation (USA); diagnostic kits for determination of glucose were from Cormay (Łomianki, Poland); $\mathrm{N}, \mathrm{N}, \mathrm{N}^{\prime}, \mathrm{N}^{\prime}$-tetramethyl ethylenediamine (TEMED) and quercetin were from Reanal (Hungary); peptone and yeast extract were from Fluka (Germany). All other chemicals were of analytical grade.

2.2. Strains and Growth Conditions. The yeast strains used in this study were the wild-type strain YPH250 (MATa trp1- $\Delta 1$ his3- $\Delta 200$ lys2-801 leu2- $\Delta 1$ ade2-101 ura3-52) and its isogenic mutants $\Delta$ sod1 (as YPH250 but sod1::URA3), $\Delta$ sod1 1 sod2 (as YPH250 but sod1::kanMX2 sod2 $\Delta:: T R P 1), \Delta c t a 1 \Delta c t t 1$ (as YPH250 but cta1::TRP1 ctt1::URA3), $\triangle y a p 1$ (as YPH250 but yap1- $1:: H I S 3$ ), and $\Delta g s h 1$ (as YPH250 but gsh1::LEU2). All strains were kindly provided by Dr. Yoshiharu Inoue (Kyoto University, Japan). Cells were grown at $28^{\circ} \mathrm{C}$ with shaking at $175 \mathrm{rpm}$ in liquid medium YPD containing $1 \%$ (w/v) yeast extract, 2\% (w/v) peptone, 2\% (w/v) glucose, and different concentrations (mM) of sodium salt of $\alpha$-ketoglutarate (AKG). $\mathrm{pH}$ value of the medium was adjusted to 5.5. The initial concentration of cells in the medium was about $0.3 \times$ $10^{6}$ cells $/ \mathrm{mL}$. Cell growth was measured as an increase in optical density at $620 \mathrm{~nm}\left(\mathrm{OD}_{620}\right)$ with microplate reader Multiskan MCC/340 (Labsystems, Helsinki, Finland). The concentration of glucose in the medium free from cells was determined using Liquick Cor-glucose kit. Results were expressed as percentage (w/v) of glucose in the medium.

2.3. Stress Treatment. Exponentially growing yeast cells were harvested after $18 \mathrm{~h}$ of cultivation, washing, and resuspension in equal volume of $50 \mathrm{mM}$ potassium phosphate buffer $(\mathrm{pH}$ 7.0) without or with adding $10 \mathrm{mM}$ AKG. Then, the aliquots of experimental suspensions were exposed to different stressors for $30 \mathrm{~min}$ at $28^{\circ} \mathrm{C}$. Yeast cells were exposed to the following stressors: $2 \mathrm{mM} \mathrm{FeSO}_{4}, 2 \mathrm{mM} \mathrm{CuSO}_{4}, 20 \% \mathrm{C}_{2} \mathrm{H}_{5} \mathrm{OH}, 100 \mathrm{mM}$ menadione, and heat shock $\left(40^{\circ} \mathrm{C}\right)$. Control cells were incubated under the same conditions but without stressors. Cell survival after stress exposure was evaluated by counting the number of colony-forming units on YPD agar plates.

2.4. Preparation of Cell-Free Extracts, Assay of Antioxidant Enzyme Activities, Protein Carbonyls, Low-Molecular Mass Thiols, and Total Protein. After $18 \mathrm{~h}$ of growth, cells from experimental or control cultures were collected by centrifugation at room temperature $(5 \mathrm{~min}, 5000 \mathrm{~g})$ and washed with $50 \mathrm{mM}$ potassium phosphate buffer ( $\mathrm{pH}$ 7.0). The yeast pellets were resuspended in lysis buffer $(50 \mathrm{mM}$ potassium phosphate buffer, $1 \mathrm{mM}$ phenylmethylsulfonyl chloride, and $0.5 \mathrm{mM}$ EDTA). Cell extracts were prepared by vortexing yeast suspensions with glass beads $(0.5 \mathrm{~mm})$ as described earlier [21] and kept on ice for immediate use.

The measurement of activities of superoxide dismutase (SOD), catalase, and glutathione reductase (GR) was conducted as described earlier [21]. The parameters were measured with a Spekol 211 spectrophotometer (Carl Zeiss, Germany) and SF-46 (LOMO, USSR). The activity of catalase was measured by monitoring disappearance of hydrogen peroxide at $240 \mathrm{~nm}$ using the extinction coefficient for hydrogen peroxide of $39.4 \mathrm{M}^{-1} \mathrm{~cm}^{-1}$ [21]. The activity of catalase was assayed in $2 \mathrm{~mL}$ of medium containing $50 \mathrm{mM}$ potassium phosphate buffer ( $\mathrm{pH}$ 7.0), $0.5 \mathrm{mM}$ EDTA, $10 \mathrm{mM} \mathrm{H}_{2} \mathrm{O}_{2}$, and $3 \mu \mathrm{L}$ of supernatant obtained as described above. The activity of SOD was assayed at $406 \mathrm{~nm}$ as the inhibition of quercetin oxidation by superoxide anion in the medium containing (final concentrations) $30 \mathrm{mM}$ Tris- $\mathrm{HCl}$ buffer $(\mathrm{pH}$ 9.0), $0.5 \mathrm{mM}$ EDTA, $0.8 \mathrm{mM}$ TEMED, $50 \mu \mathrm{M}$ quercetin, and $1-25 \mu \mathrm{L}$ of cell extract in a final volume of $1.5 \mathrm{~mL}$ [21]. One unit of SOD activity was defined as the amount of soluble protein of supernatant that inhibited the maximal rate of quercetin oxidation by $50 \%$. The activity of glutathione reductase (GR) was measured following the consumption of $\mathrm{NADPH}$ in reaction medium containing $50 \mathrm{mM}$ potassium phosphate buffer ( $\mathrm{pH}$ 7.0), 0.5 mM EDTA, $1.0 \mathrm{mM}$ oxidized glutathione, $0.25 \mathrm{mM} \mathrm{NADPH}$, and $50 \mu \mathrm{L}$ of supernatant in a final volume of $1 \mathrm{~mL}$. NADPH oxidation by GR was registered at $340 \mathrm{~nm}$ and the extinction coefficient for the coenzyme of $6220 \mathrm{M}^{-1} \cdot \mathrm{cm}^{-1}$ was used [21]. One unit of catalase and GR activities was defined as the amount of the enzyme consuming $1 \mu \mathrm{mol}$ of substrate per minute; the activities were expressed as international units (or milliunits) per milligram of the soluble protein. 
The content of carbonyl groups in proteins (CP) was measured by determining the amount of 2,4-dinitrophenylhydrazone formed upon the reaction with 2,4-dinitrophenylhydrazine [22]. Carbonyl content was calculated from the absorbance maximum of 2,4-dinitrophenylhydrazone measured at $370 \mathrm{~nm}$ using an extinction coefficient of $22 \times$ $10^{3} \mathrm{M}^{-1} \cdot \mathrm{cm}^{-1}$. The values are expressed as nanomoles of $\mathrm{CP}$ per milligram of protein.

Thiol-containing compounds were measured in cellular extracts by the light absorption of thiol conjugates with 5,5'-dithiobis-2-nitrobenzoic acid (DTNB) at $412 \mathrm{~nm}$ [23]. For determination of nonprotein low-molecular mass thiols (L-SH), aliquots of the cell extracts were mixed with $10 \%$ trichloroacetic acid (final concentration) and centrifuged $\left(13,000 \mathrm{~g}, 5 \mathrm{~min}, 21^{\circ} \mathrm{C}\right)$ to remove pelleted protein and the final supernatants were used for assay. For that, aliquots of the supernatant were incubated for 30 min with $50 \mu \mathrm{M}$ DTNB in $100 \mathrm{mM}$ Tris-HCl buffer (pH 9.0). Absorption was read at $412 \mathrm{~nm}$ and a molar extinction coefficient of $14 \times 10^{3} \mathrm{M}^{-1} \mathrm{~cm}^{-1}$ was used to calculate thiol level. Thiol levels were expressed as nanomoles of SH-groups per $10^{8}$ cells.

Protein concentration was determined by the Bradford assay with Coomassie G-250 [24] with bovine serum albumin as a standard.

2.5. Assay of Metabolic Activity. Yeast suspensions, containing $3 \times 10^{8}$ cells, were harvested by centrifugation at $3000 \mathrm{~g}$ for $5 \mathrm{~min}$ and washed twice with distilled water with previous procedure. The yeast pellets were resuspended in $1 \mathrm{~mL}$ of $50 \mathrm{mM}$ potassium phosphate buffer ( $\mathrm{pH} 7.0)$ and mixed with $0.35 \mathrm{~mL}$ of $0.5 \%$ 2,3,5-triphenyl tetrazolium chloride (TTC). Metabolically active cells are capable of reducing the dye to a water-insoluble red formazan that was extracted from the cells with ethanol/acetone mixture $(2: 1)$, and the absorbance of this solution was measured at $485 \mathrm{~nm}[25,26]$. Metabolic activity was expressed in units of optical density at $485 \mathrm{~nm}$ per $10^{8}$ cells.

2.6. Native Polyacrylamide Gel Electrophoresis. Native polyacrylamide gel electrophoresis (PAGE) was performed on $3.6 \%$ stacking and $7.5 \%$ separating gels in standard Trisglycine buffer ( $\mathrm{pH}$ 8.3) according to the method of Davis [27]. The supernatants obtained as described above were mixed with glycerol $(2: 1)$ and the samples containing $10 \mu \mathrm{g}$ amount of total protein were applied to each well. Electrophoresis was performed at $200 \mathrm{~V}$ through the stacking gel for $30 \mathrm{~min}$ and $180 \mathrm{~V}$ through the separating gel for $5 \mathrm{~h}$. Catalase activity was visualized by incubating the gels in $0.003 \% \mathrm{H}_{2} \mathrm{O}_{2}$ for $15 \mathrm{~min}$ at room temperature, followed by treatment with solution, containing $2 \%(\mathrm{w} / \mathrm{v}) \mathrm{FeCl}_{3}$ and $2 \%(\mathrm{w} / \mathrm{v})\left[\mathrm{K}_{3} \mathrm{Fe}(\mathrm{CN})_{6}\right]$ [28]. Relative band intensities were estimated with TotalLab Quant Software.

2.7. Statistical Analysis. Experimental data are expressed as the mean value of 4-8 independent experiments \pm the standard error of the mean (SEM). For statistical analysis of data, Student's $t$-test and Dunnett's test were used to compare samples with AKG versus control ones.

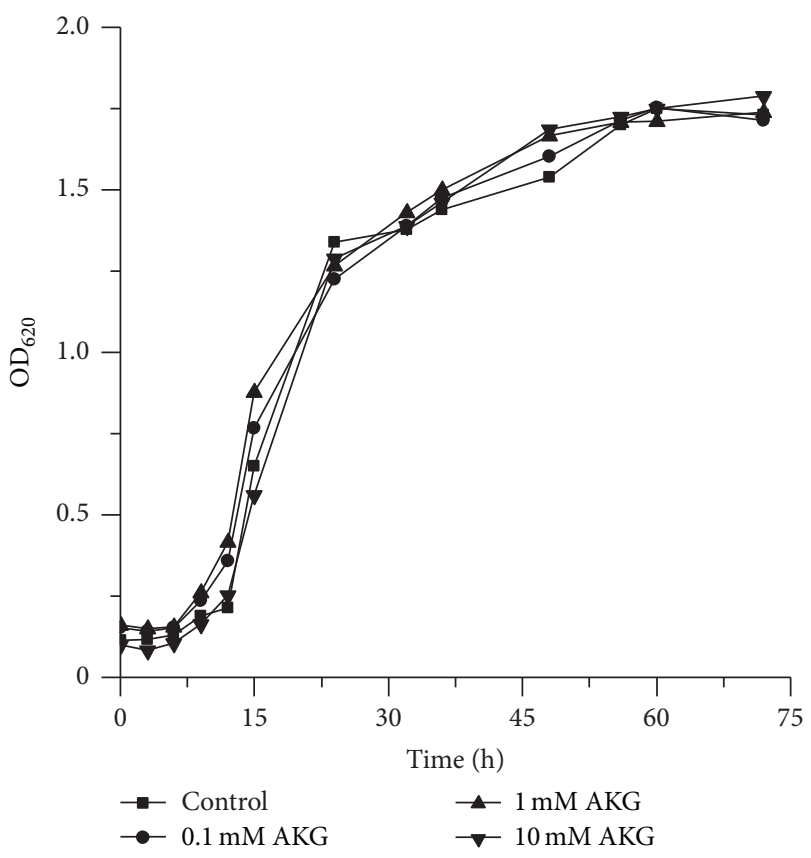

FIGURE 1: Growth curves of S. cerevisiae YPH250 in YPD medium in the presence of AKG at different concentrations. Growth was monitored by measuring the absorbance at $620 \mathrm{~nm}\left(\mathrm{OD}_{620}\right)$.

\section{Results}

3.1. Alpha-Ketoglutarate Does Not Affect Yeast Growth. Many chemicals can affect yeast growth in dose-dependent manner being toxic at their higher levels $[21,29]$. Therefore, we examined the yeast growth in YPD medium supplemented with different concentrations of AKG. The ketoacid at concentrations of $0.1-10.0 \mathrm{mM}$ did not influence the growth rate of $S$. cerevisiae YPH250 (wild type) (Figure 1). Virtually, the same results were observed for mutant strains deficient in cytosolic and peroxisomal catalases ( $\Delta c t a 1 \Delta c t t 1$ strain), cytosolic $\mathrm{Cu}, \mathrm{Zn}-\mathrm{SOD}(\Delta$ sodl strain), cytosolic $\mathrm{Cu}, \mathrm{Zn}-\mathrm{SOD}$ and mitochondrial Mn-SOD ( $\Delta$ sodi $\Delta$ sod 2 strain), $\gamma$-glutamylcysteine synthetase, a key enzyme of glutathione biosynthesis $(\Delta g s h 1$ strain), and oxidative stress regulator protein Yap1 ( $\triangle$ yap1 strain) (Table 1). The presence of AKG in the medium had little or no effect on growth rate of yeast mutants in batch cultures, although some differences were observed in growth rates between strains. The $\Delta$ sod 1 and $\Delta \operatorname{sod} 1 \Delta$ sod 2 strains grew more slowly than other strains, which is consistent with previous literature data [30].

3.2. Growth with AKG Increases Stress Resistance of Yeast Cells in Stressor- and Strain-Dependent Manner. Yeast cells grown without or with AKG were harvested at middle exponential phase, resuspended in $50 \mathrm{mM}$ potassium phosphate buffer ( $\mathrm{pH}$ 7.0), and then treated with different stressors. Figure 2(a) demonstrates survival of wild-type YPH250 cells grown with AKG at different concentrations and treated with $10 \mathrm{mM}$ $\mathrm{H}_{2} \mathrm{O}_{2}$. Cell viability in control cultures (without AKG) upon treatment with $10 \mathrm{mM} \mathrm{H}_{2} \mathrm{O}_{2}$ amounted to $45 \%$ of the untreated cell viability. The growth with $0.1 \mathrm{mM}$ AKG did 
TABLE 1: Growth of different S. cerevisiae strains measured by absorbance at $620 \mathrm{~nm}\left(\mathrm{OD}_{620}\right)$ at certain time periods.

\begin{tabular}{lccccccc}
\hline \multirow{2}{*}{ Growth conditions } & \multirow{2}{*}{ Time, $\mathrm{h}$} & YPH250 & $\Delta$ cta1 $\Delta$ ctt1 & $\Delta$ sod1 & $\Delta$ sod1 $\operatorname{sod} 2$ & $\Delta$ ssh1 & $\Delta$ yap1 \\
\hline & 0 & $0.095 \pm 0.015$ & $0.085 \pm 0.010$ & $0.105 \pm 0.015$ & $0.087 \pm 0.015$ & $0.107 \pm 0.015$ & $0.88 \pm 0.012$ \\
& 6 & $0.117 \pm 0.020$ & $0.099 \pm 0.011$ & $0.127 \pm 0.023$ & $0.097 \pm 0.011$ & $0.111 \pm 0.021$ & $0.139 \pm 0.030$ \\
Control (without AKG) & 15 & $1.012 \pm 0.035$ & $0.946 \pm 0.099$ & $0.195 \pm 0.045^{*}$ & $0.658 \pm 0.055^{*}$ & $1.125 \pm 0.065$ & $1.306 \pm 0.134$ \\
& 24 & $1.178 \pm 0.086$ & $1.185 \pm 0.058$ & $1.014 \pm 0.045$ & $1.119 \pm 0.074$ & $1.224 \pm 0.125$ & $1.558 \pm 1.155$ \\
& 48 & $1.575 \pm 0.135$ & $1.381 \pm 0.125$ & $1.248 \pm 0.107^{*}$ & $1.321 \pm 0.085^{*}$ & $1.505 \pm 0.110$ & $1.68 \pm 0.215$ \\
\hline & 0 & $0.098 \pm 0.016$ & $0.083 \pm 0.012$ & $0.102 \pm 0.017$ & $0.085 \pm 0.011$ & $0.101 \pm 0.011$ & $0.095 \pm 0.013$ \\
10 mM AKG & 6 & $0.105 \pm 0.012$ & $0.098 \pm 0.013$ & $0.115 \pm 0.018$ & $0.099 \pm 0.011$ & $0.115 \pm 0.025$ & $0.115 \pm 0.025$ \\
& 15 & $1.075 \pm 0.058$ & $0.954 \pm 0.065$ & $0.233 \pm 0.048^{*}$ & $0.656 \pm 0.065^{*}$ & $1.154 \pm 0.077$ & $1.325 \pm 0.145$ \\
& 24 & $1.179 \pm 0.046$ & $1.195 \pm 0.095$ & $1.121 \pm 0.098$ & $1.103 \pm 0.105$ & $1.248 \pm 0.095$ & $1.611 \pm 0.173$ \\
& 48 & $1.601 \pm 0.103$ & $1.377 \pm 0.141$ & $1.310 \pm 0.138^{*}$ & $1.331 \pm 0.076^{*}$ & $1.550 \pm 0.125$ & $1.672 \pm 0.185$ \\
\hline
\end{tabular}

Cells were cultured in YPD medium supplemented with $10 \mathrm{mM}$ AKG. The starting cell concentration was about $0.3 \times 10^{6}$ cells $/ \mathrm{mL}$. Data are means \pm SEM, $n=3$. $^{*}$ Significant difference from respective values for YPH250 (wide type) strain with $P<0.05$ using Student's $t$-test.

TABLE 2: Effect of different stressors on survival (\%) of S. cerevisiae YPH250 cells grown in the absence (control) or presence of $10 \mathrm{mM}$ AKG.

\begin{tabular}{lcc}
\hline Stressor & Control & $10 \mathrm{mM} \mathrm{AKG}$ \\
\hline $2 \mathrm{mM} \mathrm{FeSO}_{4}$ & $49 \pm 3$ & $63 \pm 5^{*}$ \\
$2 \mathrm{mM} \mathrm{CuSO}_{4}$ & $40 \pm 3$ & $58 \pm 6^{*}$ \\
$20 \%$ ethanol & $31 \pm 3$ & $28 \pm 2$ \\
$100 \mathrm{mM}^{2}$ menadione & $54 \pm 4$ & $67 \pm 4^{*}$ \\
Heat shock $\left(40^{\circ} \mathrm{C}\right)$ & $20 \pm 3$ & $21 \pm 3$ \\
\hline
\end{tabular}

Exponentially growing cells were exposed to different stressors for $30 \mathrm{~min}$. Survival of yeast cells in respective suspensions without treatment with stressors was accepted as $100 \%$. Data are means \pm SEM, $n=5-6$. ${ }^{*}$ Significantly different from respective control values with $P<0.05$ using Student's $t$-test.

not influence yeast susceptibility to $10 \mathrm{mM} \mathrm{H}_{2} \mathrm{O}_{2}$, whereas stress survival of YPH250 cells grown with 1 and $10 \mathrm{mM} \mathrm{AKG}$ was $15 \%$ and $20 \%$ higher, respectively, than that of control cells. Thus, the cultivation in AKG-supplemented medium can enhance resistance of $S$. cerevisiae cells to $\mathrm{H}_{2} \mathrm{O}_{2}$.

Given that the most pronounced effect on yeast resistance to $\mathrm{H}_{2} \mathrm{O}_{2}$ was observed at cultivation with $10 \mathrm{mM} \mathrm{AKG}$, this AKG concentration was used in all next experiments. Table 2 presents the results of growth in AKG-supplemented medium on yeast survival under followed exposure to different stress factors: $2 \mathrm{mM} \mathrm{Fe}{ }^{2+}, 2 \mathrm{mM} \mathrm{Cu}{ }^{2+}, 20 \% \mathrm{C}_{2} \mathrm{H}_{5} \mathrm{OH}, 100 \mathrm{mM}$ menadione, and heat shock $\left(40^{\circ} \mathrm{C}\right)$. Survival of $\mathrm{S}$. cerevisiae YPH250 cells in control cultures (without AKG) was substantially reduced by treatment with these stressors. Yeast cells grown in the presence of $10 \mathrm{mM}$ AKG showed $22 \%, 28 \%$, and $45 \%$ higher survival after exposure to $20 \mathrm{mM}$ menadione, $2 \mathrm{mM} \mathrm{Fe}^{2+}$, and $2 \mathrm{mM} \mathrm{Cu}^{2+}$, respectively, as compared to control ones. At the same time, growth on AKG did not affect yeast resistance to $20 \%$ ethanol and heat shock.

To find which component of yeast antioxidant defense system could be important for resistance to $\mathrm{H}_{2} \mathrm{O}_{2}$ in AKGgrown wild-type cells, we investigated the strains deficient in certain antioxidant enzymes and Yap1 protein, a transcription factor coordinating yeast response to oxidative
TABLE 3: Total metabolic activity and selected characteristics of ROS homeostasis in S. cerevisiae YPH250 cells grown in the absence (control) or presence of $10 \mathrm{mM} \mathrm{AKG.}$

\begin{tabular}{lcc}
\hline Parameter & Control & $10 \mathrm{mM} \mathrm{AKG}$ \\
\hline Metabolic activity, & $0.256 \pm 0.020$ & $0.327 \pm 0.008^{*}$ \\
OD $_{485} / 10^{8}$ cells & $187 \pm 13$ & $185 \pm 18$ \\
SOD, U/mg protein & $25.3 \pm 3.9$ & $85.0 \pm 17.1^{*}$ \\
GR, mU/mg protein & $20.3 \pm 1.8$ & $32.7 \pm 1.9^{*}$ \\
\hline
\end{tabular}

Data are means \pm SEM, $n=5-6 .{ }^{*}$ Significantly different from respective values in control cultures with $P<0.05$ using Student's $t$-test.

stress. The data are presented in Figures 2(b) and 2(c). In control cultures, $\Delta$ sod1, $\Delta$ ctal $\Delta c t t 1$, and $\Delta y a p 1$ cells showed higher susceptibility to $\mathrm{H}_{2} \mathrm{O}_{2}$ than parental YPH250 strain. Tolerance to $\mathrm{H}_{2} \mathrm{O}_{2}$ in $\Delta \operatorname{sod} 1 \Delta \operatorname{sod} 2$ and $\Delta g \operatorname{sh} 1$ mutants was similar to that of $\mathrm{YPH} 250$ strain. Under $\mathrm{H}_{2} \mathrm{O}_{2}$ exposure, $\Delta$ sod1, $\Delta y a p 1$, and $\Delta g s h 1$ cells grown on AKG showed 1.62.6-fold higher stress survival compared to cells in control suspensions. Growth on $10 \mathrm{mM}$ AKG did not affect sensitivity of $\Delta \operatorname{sod} 1 \Delta \operatorname{sod} 2$ and $\Delta$ cta1 $\Delta$ ctt1 cells to $\mathrm{H}_{2} \mathrm{O}_{2}$. The direct addition of $10 \mathrm{mM}$ AKG to incubation medium containing $10 \mathrm{mM} \mathrm{H}_{2} \mathrm{O}_{2}$ enhanced 3.5-fold survival of $\Delta$ cta1 $\Delta c t t 1$ cells from control cultures compared to the same cells subjected only to $\mathrm{H}_{2} \mathrm{O}_{2}$ (Figure 2(c)).

3.3. Cultivation with AKG Enhances Antioxidant Defense Capacity in Yeast. To determine if the positive effects of AKG on resistance to stresses were connected with changes in yeast metabolism, in particular with oxidative processes, we measured total metabolic activity of yeast cells, activities of several antioxidant enzymes, and levels of oxidative stress indices. For these experiments, YPH250 cells grown with $10 \mathrm{mM} \mathrm{AKG}$ were used. Growth on AKG promoted 30\% and 60\% higher metabolic activity and concentration of low-molecular mass thiols (L-SH), respectively, compared to control conditions (Table 3). SOD activity was similar, while the activities of glutathione reductase (GR) (Table 3) and catalase (Figure 3(a)) 


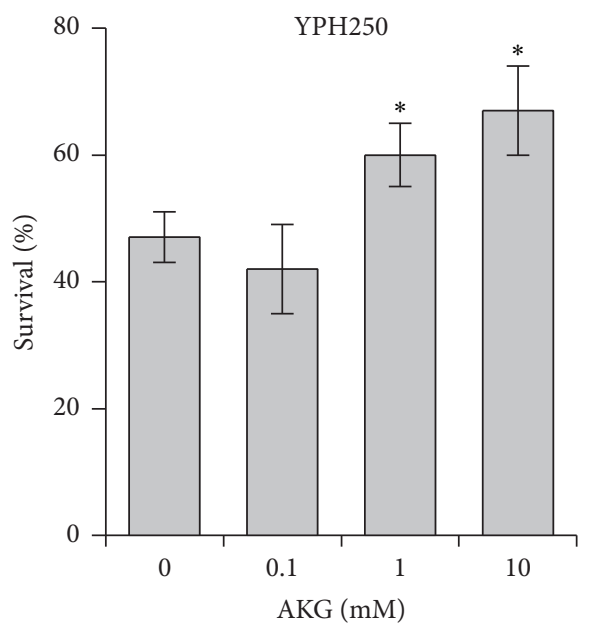

(a)

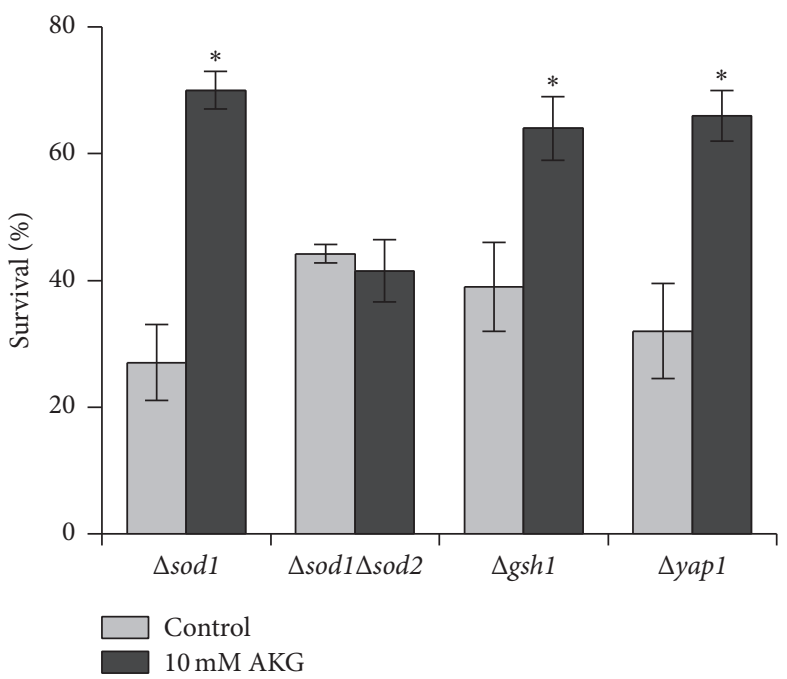

(b)

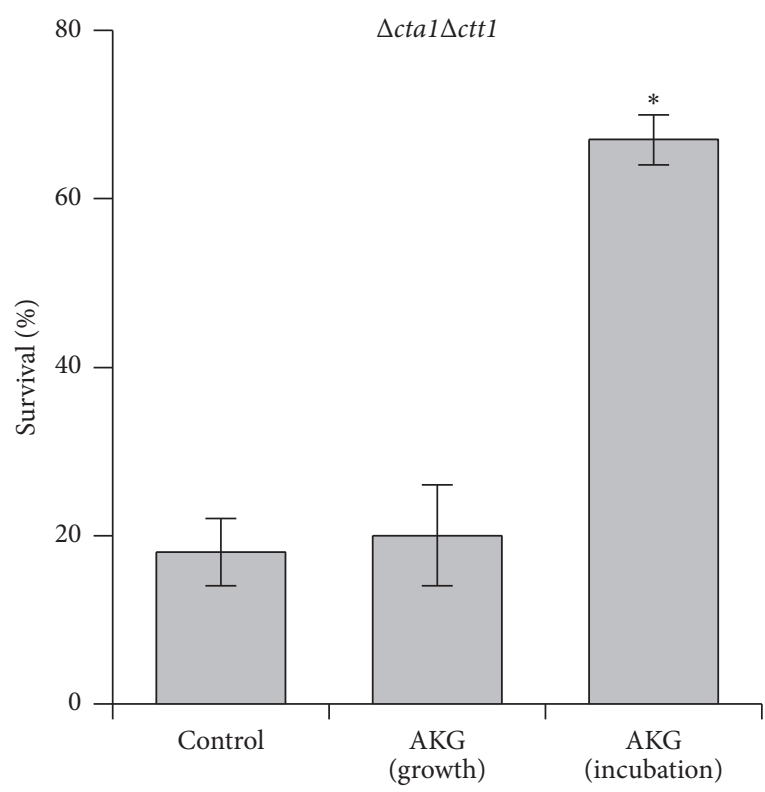

(c)

Figure 2: Effect of exposure to $10 \mathrm{mM} \mathrm{H}_{2} \mathrm{O}_{2}$ for $30 \mathrm{~min}$ on cell survival in S. cerevisiae YPH250 strain and its isogenic derivatives grown in the absence or presence of $10 \mathrm{mM}$ AKG. (a) YPH250 cells (wild type) grown with AKG different concentrations; (b) mutant cells grown without or with $10 \mathrm{mM} \mathrm{AKG;} \mathrm{(c)} \Delta c t a 1 \Delta c t t 1$ cells grown without or with AKG and were treated with only $10 \mathrm{mM} \mathrm{H}_{2} \mathrm{O}_{2}$ denoted as "control" and "AKG (growth)," respectively; "AKG (incubation)," $\Delta c t a 1 \Delta c t t 1$ cells grown without AKG were treated with $10 \mathrm{mM} \mathrm{H}_{2} \mathrm{O}_{2}$ in combination with $10 \mathrm{mM}$ AKG. Data are means \pm SEM, $n=5-6 .{ }^{*}$ Significantly different from respective control values with $P<0.05$ using Dunnett's test (a) or Student's $t$-test (b, c).

were 3.4-fold and 1.3-fold higher, respectively, in AKG-grown cells compared to control cells. Using native PAGE followed by the quantification of the enzyme activities, we showed that the catalase isoforms' bands were different in cells from control and AKG-supplemented cultures (Figure 4). Peroxisomal catalase A band had 1.4-fold higher intensity in AKG-grown cells, while the cytosolic catalase $\mathrm{T}$ band did not differ significantly from the control one. Hence, the higher total catalase activity in AKG-grown cells could be connected with enhanced level of peroxisomal isoform of catalase.
Treatment with $10 \mathrm{mM} \mathrm{H}_{2} \mathrm{O}_{2}$ decreased catalase activity in control and AKG-grown cells by $68 \%$ and $55 \%$, respectively (Figure 3(a)). The level of protein carbonyl groups (CP) which is widely used for evaluation of the intensity of protein oxidation $[21,22]$ did not differ in control and AKG-grown cells (Figure 4). Treatment with $10 \mathrm{mM} \mathrm{H}_{2} \mathrm{O}_{2}$ led to a 2.2-fold increase of CP level in control cells and did not change this parameter in cells grown on AKG (Figure 3(b)). The results suggest that AKG-grown cells were more resistant to $\mathrm{H}_{2} \mathrm{O}_{2}$ induced damage than the control ones. 


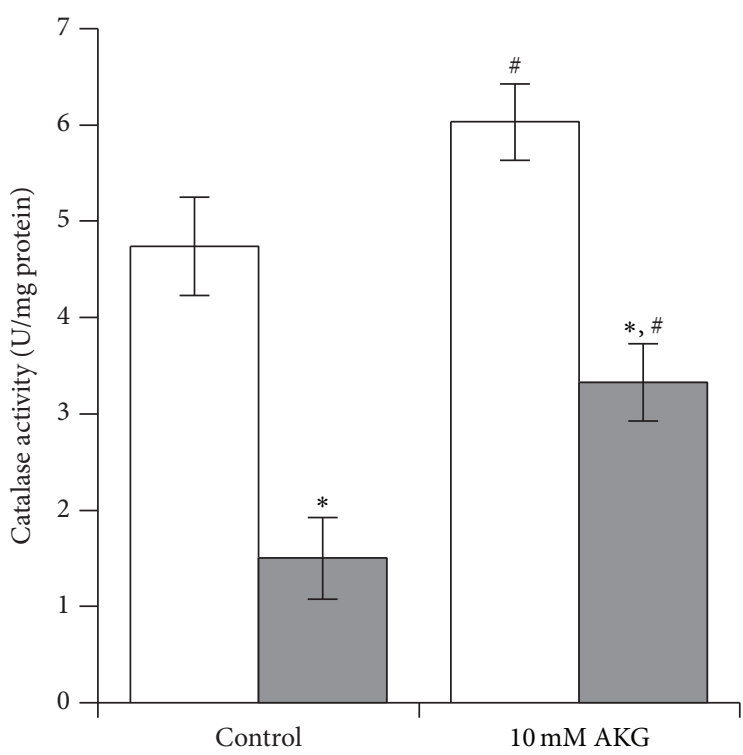

(a)

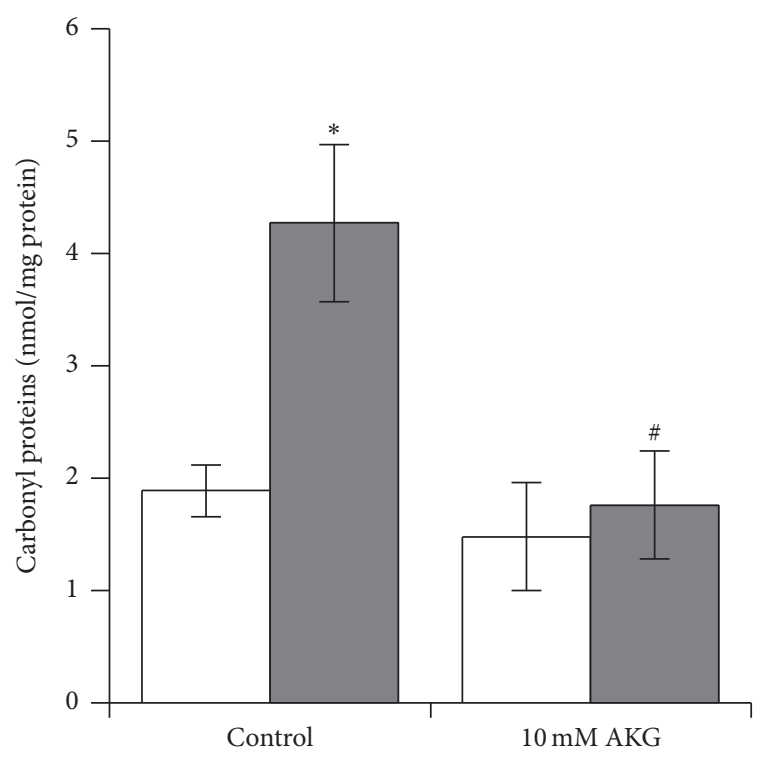

(b)

Figure 3: Effect of exposure to $10 \mathrm{mM} \mathrm{H}_{2} \mathrm{O}_{2}$ for 30 min on catalase activity (a) and level of protein carbonyls (b) in S. cerevisiae YPH250 cells grown in the absence or presence of $10 \mathrm{mM}$ AKG. Untreated cells (without $\mathrm{H}_{2} \mathrm{O}_{2}$ ) and cells treated with $10 \mathrm{mM} \mathrm{H}_{2} \mathrm{O}_{2}$ are marked by white square and grey square bars, respectively. Data are means \pm SEM, $n=5-6 .{ }^{*}$ Significantly different from respective values of untreated cells and " from respective values of control group (without AKG) with $P<0.05$ using Student's $t$-test, $n=5-6$.

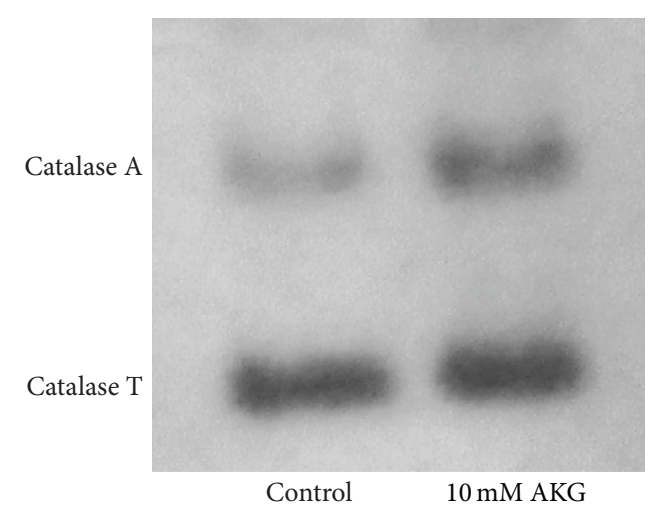

FIGURE 4: Native PAGE electrophoresis of catalase isoforms in $S$. cerevisiae YPH250 cells grown in the absence or presence of $10 \mathrm{mM}$ AKG. An amount of total protein applied to each well was $10 \mu \mathrm{g}$.

\section{Discussion}

Alpha-ketoglutarate, an endogenous intermediate in the Krebs cycle, is a molecule involved in cellular energetics and amino acid metabolism. Many studies demonstrate that in different cases of induced oxidative stress under in vitro or in vivo conditions, AKG have antioxidant properties [6$11,17]$ as well as the capacity of endogenous antioxidant defense thus affecting stress resistance of organisms [12, 13]. In particular, we found previously that AKG-enriched diet enhanced antioxidant defense capacity and cold stress tolerance in young D. melanogaster adults [13]. In this work, we showed that growth in AKG-enriched medium increased resistance to stresses in unicellular yeast $S$. cerevisiae, but the effects depended on the concentration of AKG, type of stressors, and gene deficiency in yeast strains. The positive effects of AKG supplement in the medium (1 and $10 \mathrm{mM}$ ) on oxidative stress resistance were obtained at relatively high concentrations. It can be connected with the fact that AKG is a charged dicarboxylate molecule and therefore it is not highly membrane permeable. Earlier, exogenous AKG was shown to enter various eukaryotic cells by different active organic anion transporter mechanisms (i.e., different $\mathrm{Na}^{+}$dicarboxylate cotransporter proteins were described) or simply by diffusion at low $\mathrm{pH}(<3.0)$ [31]. In S. cerevisiae, dicarboxylate transporters have not been studied well and they are mainly represented by low-specific $\mathrm{H}^{+}$/dicarboxylate symporters. The transport mechanism is reversible, accumulative, and dependent on the transmembrane gradient of the substrate [32]. Thus, we can suppose that, at higher concentrations in the medium, exogenous AKG can more actively enter the yeast cell leading to reorganization and/or intensification of cellular metabolic processes. Our data on the total metabolic activity support the increase in metabolic rate in yeast cells grown on AKG. The metabolic activity was measured by reduction of colorless tetrazolium salt (TTC) yielding red formazan. The reaction occurs in the mitochondria where TTC is reduced at different sites along the electron-transport chain [25]. One can suppose that cells grown in the presence of AKG respire more actively than their counterparts grown under control conditions. It is known that the Krebs cycle and respiratory chain are poorly active in S. cerevisiae cells growing at high glucose levels. Glucose is preferentially metabolized via glycolysis to form nonfermentable carbon compounds, mainly ethanol. The genes encoding Krebs cycle enzymes are also downregulated 
by high levels of glucose [33]. In S. cerevisiae, the inhibitory effect of glucose is canceled at its concentrations lower than $0.2 \%$ and depletion of glucose increases 3-10 times levels of mRNAs of Krebs cycle enzymes [34]. In our experiments, the glucose concentrations at $18 \mathrm{~h}$ of growth in the media collected from control and AKG-grown yeast cultures were $0.113 \pm 0.028$ and $0.104 \pm 0.021 \%$, respectively. Hence, the cells were not under glucose repression and characterized by an increase in flux through the Krebs cycle. Therefore, it may be supposed that exogenous AKG can penetrate the cells and be included in Krebs cycle where it is oxidatively decarboxylated to succinyl-CoA by the $\alpha$-ketoglutarate dehydrogenase complex yielding also NADH. In line with this, the ability of AKG to increase respiration and oxidative phosphorylation was found earlier in rat liver [35]. AKGmediated intensification of mitochondrial respiration can lead to increase in the level of ROS as by-products of respiratory metabolism $[18,25]$. In addition, ROS can be formed as side products of AKG oxidative decarboxylation catalyzed by $\alpha$-ketoglutarate dehydrogenase complex [36]. Small increase in ROS level may induce mild oxidative stress which results in the induction of antioxidant defense $[1,13,18,19,37]$. This assumption is confirmed by the increased activities of catalase and GR and higher level of low-molecular mass thiols in AKG-grown yeast cells. The low-molecular mass thiols are represented mainly by glutathione and increased level of L$\mathrm{SH}$ could result from either enhanced level of precursors of glutamine or enhanced expression of key enzymes of glutathione biosynthesis [38]. Given that the ability of AKG to serve as a glutamate precursor for glutathione biosynthesis was shown earlier in human erythrocytes [14], we suppose that in our experiments externally added AKG could be used for glutathione biosynthesis resulting in increased L-SH level.

Mild oxidative stress is known to preadapt organisms to lethal oxidative and other stresses $[1,18,26,37,39]$. Thus, the increase in antioxidant defense as a result of mild oxidative stress can explain higher resistance of AKG-grown YPH250 cells to $\mathrm{H}_{2} \mathrm{O}_{2}$, menadione, and $\mathrm{Fe}^{2+}$ and $\mathrm{Cu}^{2+}$ ions. These stressors are directly connected with development of oxidative stress: menadione is a compound generating $\mathrm{O}_{2}{ }^{--}$ [39] and $\mathrm{Fe}^{2+} / \mathrm{Cu}^{2+}$ can interact with $\mathrm{H}_{2} \mathrm{O}_{2}$ in Fenton reaction with generation of high reactive hydroxyl radical [1]. Growth with AKG did not improve yeast resistance to ethanol and heat shock. Both ethanol and heat shock can lead to enhanced ROS production, but it seems that other mechanisms of the stressors are more involved in yeast death, and these mechanisms cannot be compensated by the increased antioxidant potential.

It was shown previously that $\mathrm{AKG}$ can detoxify $\mathrm{H}_{2} \mathrm{O}_{2}$ and provide an effective protection against oxidative stress $[6,8,11]$. The direct antioxidant action of AKG in our experiments is an unlikely explanation. AKG-grown yeast cells were exposed to stressors after removal of culture medium, and the protective effect could be only ensured by AKG absorbed by the cells during this time. Given that AKG is rapidly metabolized $[16,17]$, the AKG-grown cells were not able to accumulate it in sufficient amounts.
Exposure to $\mathrm{H}_{2} \mathrm{O}_{2}$ increased CP level in control YPH250 cells but not in AKG-grown cells, which had also better viability under the stress. One may suppose that AKGtreated cells undergo less oxidative damage under $\mathrm{H}_{2} \mathrm{O}_{2}$ exposure. To support this, the substantial decrease in catalase activity in control cells treated with $\mathrm{H}_{2} \mathrm{O}_{2}$ was observed as compared with yeast cells grown in the presence of AKG. The possibility of inactivation of antioxidant enzymes due to oxidative modification has been already shown in our previous studies $[29,40]$. Obviously, higher capacity of antioxidant system provides more effective protection in AKG-grown cells against $\mathrm{H}_{2} \mathrm{O}_{2}$-induced damage.

To elucidate which components of antioxidant system were important for realization of stress-protective effects of AKG, we examined resistance to hydrogen peroxide in the yeast strains with defects in antioxidant defense. Growth on AKG increased resistance to $\mathrm{H}_{2} \mathrm{O}_{2}$ in $\Delta$ sodl, syapl, and $\Delta g s h 1$ cells but did not improve stress resistance in $\Delta \operatorname{sod} 1 \Delta \operatorname{sod} 2$ and $\Delta$ ctal $\Delta c t t 1$ mutants. The results suggest that cytosolic $\mathrm{Cu}, \mathrm{Zn}-\mathrm{SOD}$, transcriptional regulator Yapl protein, or $\gamma$-glutamylcysteine synthetase, an enzyme participating in glutathione synthesis, are not crucial components for the AKG-mediated protective effects. At the same time, the presence of two SOD isoenzymes or catalase isoenzymes is required for stress-protective effects of AKG. The importance of catalase is confirmed by the increased activity of this enzyme, in particular its peroxisomal isoform, in wild-type cells grown on AKG. AKG is metabolized preferentially in mitochondria; therefore the importance of mitochondrial SOD2 in the removal of ROS produced was expected. The importance of both, SOD and catalase, in response of $S$. cerevisiae to $\mathrm{H}_{2} \mathrm{O}_{2}$ is proved by numerous previous studies $[19,39,40]$. Furthermore, since increase in oxidative stress resistance was observed in $\Delta y a p 1$ mutant grown on AKG, the induction of antioxidant defense on AKG-supplemented medium seems to occur via not only Yap1-mediated pathways. Other transcriptional factors such as Msn2/4 or Skn7 are known to be involved in adaptive response of yeast to oxidative stress $[20,29]$. It should be noted that $\Delta c t a 1 \Delta c t t 1$ cells treated simultaneously with $\mathrm{H}_{2} \mathrm{O}_{2}$ and AKG survived significantly better compared to cells treated with $\mathrm{H}_{2} \mathrm{O}_{2}$ only. It points out to the antioxidant mode of $\mathrm{AKG}$ action in the protection of yeast cells against $\mathrm{H}_{2} \mathrm{O}_{2}$ in cotreatment as it was observed earlier [5]. It also confirms that AKG can act as an antioxidant in combined treatment with oxidants, but its antioxidant properties are not sufficient for protection when cells were grown on AKG, possibly due to fast intracellular metabolism of AKG.

\section{Conclusions}

The obtained results suggest that growth on AKG-supplemented medium increases resistance of yeast $S$. cerevisiae to oxidative stress but not to heat shock and ethanol stress. The protective effect of AKG seems to be due to the enhancement of the cellular energetic metabolism and synthesis of protective proteins. Intensification of metabolic processes is accomplished by the induction of mild oxidative stress resulting in the activation of antioxidant system in yeast cells. In turn, 
enhanced antioxidant defense confers yeast resistance to oxidants and of transition metal ions. Both isoenzymes of SOD or catalase are required for stress-protective effects of AKG. Given these facts the detailed molecular mechanisms of AKG action, in particular the involvement of master transcription regulators of stress response Msn2/4p and Yap1, should be addressed for future studies.

\section{Competing Interests}

The authors declare that there is no conflict of interests regarding the publication of this paper.

\section{Acknowledgments}

The authors are grateful to Dr. Y. Inoue for providing the $S$. cerevisiae strains. Dr. D. Gospodaryov is acknowledged for critical reading of the manuscript and correcting English; especial thanks are due to our students L. Izerska, Kh. I. Hryshuk, and J. Sofin'ska for technical assistance. The authors thank U. Dzaman, M.S., for English editing.

\section{References}

[1] V. I. Lushchak, "Free radicals, reactive oxygen species, oxidative stress and its classification," Chemico-Biological Interactions, vol. 224, pp. 164-175, 2014.

[2] V. Rani, G. Deep, R. K. Singh, K. Palle, and U. C. S. Yadav, "Oxidative stress and metabolic disorders: pathogenesis and therapeutic strategies," Life Sciences, vol. 148, pp. 183-193, 2016.

[3] S. Bednarska, P. Leroy, M. Zagulski, and G. Bartosz, "Efficacy of antioxidants in the yeast Saccharomyces cerevisiae correlates with their effects on protein thiols," Biochimie, vol. 90, no. 10, pp. 1476-1485, 2008.

[4] V. Conti, V. Izzo, G. Corbi et al., "Antioxidant supplementation in the treatment of aging-associated diseases," Frontiers in Pharmacology, vol. 7, article 24, 2016.

[5] M. M. Bayliak, N. I. Burdylyuk, and V. I. Lushchak, "Quercetin increases stress resistance in the yeast Saccharomyces cerevisiae not only as an antioxidant," Annals of Microbiology, vol. 66, no. 2, pp. 569-576, 2016.

[6] M. Sokołowska, A. Oleszek, and L. Włodek, "Protective effect of $\alpha$-keto acids on the oxidative hemolysis," Polish Journal of Pharmacology, vol. 51, no. 5, pp. 429-434, 1999.

[7] R. L. Puntel, C. W. Nogueira, and J. B. Rocha, "Krebs cycle intermediates modulate thiobarbituric acid reactive species (TBARS) production in rat brain in vitro," Neurochemical Research, vol. 30, no. 2, pp. 225-235, 2005.

[8] M. M. Bayliak, M. P. Lylyk, O. M. Vytvytska, and V. I. Lushchak, "Assessment of antioxidant properties of alpha-keto acids in vitro and in vivo," European Food Research and Technology, vol. 242, no. 2, pp. 179-188, 2016.

[9] S. Velvizhi, T. Nagalashmi, M. M. Essa, K. B. Dakshayani, and P. Subramanian, "Effects of $\alpha$-ketoglutarate on lipid peroxidation and antioxidant status during chronic ethanol administration in wistar rats," Polish Journal of Pharmacology, vol. 54, no. 3, pp. 231-236, 2002.

[10] R. Bhattacharya, R. M. Satpute, J. Hariharakrishnan, H. Tripathi, and P. B. Saxena, "Acute toxicity of some synthetic cyanogens in rats and their response to oral treatment with alpha-ketoglutarate," Food and Chemical Toxicology, vol. 47, no. 9, pp. 2314-2320, 2009.

[11] M. M. Bayliak, H. V. Shmihel, M. P. Lylyk et al., "Alphaketoglutarate attenuates toxic effects of sodium nitroprusside and hydrogen peroxide in Drosophila melanogaster," Environmental Toxicology and Pharmacology, vol. 40, no. 2, pp. 650-659, 2015.

[12] T. Niemiec, J. Sikorska, A. Harrison et al., "Alpha-ketoglutarate stabilizes redox homeostasis and improves arterial elasticity in aged mice," Journal of Physiology and Pharmacology, vol. 62, no. 1, pp. 37-43, 2011.

[13] M. M. Bayliak, M. P. Lylyk, H. V. Shmihel et al., "Dietary alpha-ketoglutarate increases cold tolerance in Drosophila melanogaster and enhances protein pool and antioxidant defense in sex-specific manner," Journal of Thermal Biology, vol. 60, pp. 1-11, 2016.

[14] S. Whillier, B. Garcia, B. E. Chapman, P. W. Kuchel, and J. E. Raftos, "Glutamine and $\alpha$-ketoglutarate as glutamate sources for glutathione synthesis in human erythrocytes," FEBS Journal, vol. 278, no. 17, pp. 3152-3163, 2011.

[15] R. M. Chin, X. Fu, M. Y. Pai et al., "The metabolite $\alpha$ ketoglutarate extends lifespan by inhibiting ATP synthase and TOR," Nature, vol. 510, no. 7505, pp. 397-401, 2014.

[16] B. D. Lambert, R. Filip, B. Stoll et al., "First-pass metabolism limits the intestinal absorption of enteral $\alpha$-ketoglutarate in young pigs," Journal of Nutrition, vol. 136, no. 11, pp. 2779-2784, 2006.

[17] B. Zdzisińska, A. Żurek, and M. Kandefer-Szerszeń, “Alphaketoglutarate as a molecule with pleiotropic activity: wellknown and novel possibilities of therapeutic use," Archivum Immunologiae et Therapiae Experimentalis, pp. 1-16, 2016.

[18] V. Costa and P. Moradas-Ferreira, "Oxidative stress and signal transduction in Saccharomyces cerevisiae: insights into ageing, apoptosis and diseases," Molecular Aspects of Medicine, vol. 22, no. 4-5, pp. 217-246, 2001.

[19] H. M. Semchyshyn and L. M. Lozinska, "Fructose protects baker's yeast against peroxide stress: potential role of catalase and superoxide dismutase," FEMS Yeast Research, vol. 12, no. 7, pp. 761-773, 2012.

[20] V. I. Lushchak, “Oxidative stress in yeast," Biochemistry, vol. 75, no. 3, pp. 281-296, 2010.

[21] V. Lushchak, H. Semchyshyn, O. Lushchak, and S. Mandryk, "Diethyldithiocarbamate inhibits in vivo $\mathrm{Cu}, \mathrm{Zn}$-superoxide dismutase and perturbs free radical processes in the yeast Saccharomyces cerevisiae cells," Biochemical and Biophysical Research Communications, vol. 338, no. 4, pp. 1739-1744, 2005.

[22] R. L. Levine, D. Garland, C. N. Oliver et al., "Determination of carbonyl content in oxidatively modified proteins," Methods in Enzymology, vol. 186, pp. 464-478, 1990.

[23] G. L. Ellman, "Tissue sulfhydryl groups," Archives of Biochemistry and Biophysics, vol. 82, no. 1, pp. 70-77, 1959.

[24] M. M. Bradford, "A rapid and sensitive method for the quantitation of microgram quantities of protein utilizing the principle of protein-dye binding," Analytical Biochemistry, vol. 72, no. 1-2, pp. 248-254, 1976.

[25] A. Conconi, P. Jager-Vottero, X. Zhang, B. C. Beard, and M. J. Smerdon, "Mitotic viability and metabolic competence in UVirradiated yeast cells," Mutation Research/DNA Repair, vol. 459, no. 1, pp. 55-64, 2000.

[26] R. Vasylkovska, N. Petriv, and H. Semchyshyn, "Carbon sources for yeast growth as a precondition of hydrogen peroxide 
induced hormetic phenotype," International Journal of Microbiology, vol. 2015, Article ID 697813, 8 pages, 2015.

[27] B. J. Davis, "Disc electrophoresis-II method and application to human serum proteins," Annals of the New York Academy of Sciences, vol. 121, no. 2, pp. 404-427, 1964.

[28] W. Woodbury and A. K. Spencer, "An improved procedure using ferricyanide for detecting catalase isozymes," Analytical Biochemistry, vol. 44, no. 1, pp. 301-305, 1971.

[29] M. M. Bayliak, N. I. Burdyliuk, L. I. Izers'ka, and V. I. Lushchak, "Concentration-dependent effects of Rhodiola rosea on longterm survival and stress resistance of yeast Saccharomyces cerevisiae: the involvement of Yap 1 and Msn2/4 regulatory proteins," Dose-Response, vol. 12, no. 1, pp. 93-109, 2014.

[30] V. D. Longo, E. B. Gralla, and J. S. Valentine, "Superoxide dismutase activity is essential for stationary phase survival in Saccharomyces cerevisiae: mitochondrial production of toxic oxygen species in vivo," Journal of Biological Chemistry, vol. 271, no. 21, pp. 12275-12280, 1996.

[31] A. M. Pajor, "Sodium-coupled transporters for krebs cycle intermediates," Annual Review of Physiology, vol. 61, pp. 663-682, 1999.

[32] M. Casal, O. Queirós, G. Talaia, D. Ribas, and S. Paiva, "Carboxylic acids plasma membrane transporters in Saccharomyces cerevisiae," Advances in Experimental Medicine and Biology, vol. 892, pp. 229-251, 2016.

[33] J. M. Gancedo, "Yeast carbon catabolite repression," Microbiology and Molecular Biology Reviews, vol. 62, no. 2, pp. 334-361, 1998.

[34] J. L. DeRisi, V. R. Iyer, and P. O. Brown, "Exploring the metabolic and genetic control of gene expression on a genomic scale," Science, vol. 278, no. 5338, pp. 680-686, 1997.

[35] N. M. Kurgalyuk and O. V. Goryn, "Effect of sodium $\alpha$ ketoglutarate injected after the $\mathrm{x}$-ray treatment on the respiration and oxidative phosphorylation of the liver's mitochondria," Fiziolohichnyı̌ Zhurnal, vol. 46, no. 5, pp. 63-70, 2000.

[36] L. Tretter and V. Adam-Vizi, "Alpha-ketoglutarate dehydrogenase: a target and generator of oxidative stress," Philosophical Transactions of the Royal Society of London, Series B, vol. 360, pp. 2335-2345, 2005.

[37] H. M. Semchyshyn, "Hormetic concentrations of hydrogen peroxide but not ethanol induce cross-adaptation to different stresses in budding yeast," International Journal of Microbiology, vol. 2014, Article ID 485792, 5 pages, 2014.

[38] V. I. Lushchak, "Glutathione homeostasis and functions: potential targets for medical interventions," Journal of Amino Acids, vol. 2012, Article ID 736837, 26 pages, 2012.

[39] P. N. Fernandes, S. C. Mannarino, C. G. Silva, M. D. Pereira, A. D. Panek, and E. C. A. Eleutherio, "Oxidative stress response in eukaryotes: effect of glutathione, superoxide dismutase and catalase on adaptation to peroxide and menadione stresses in Saccharomyces cerevisiae," Redox Report, vol. 12, no. 5, pp. 236244, 2007.

[40] M. Bayliak, H. Semchyshyn, and V. Lushchak, "Effect of hydrogen peroxide on antioxidant enzyme activities in Saccharomyces cerevisiae is strain-specific," Biochemistry, vol. 71, no. 9, pp. 10131020, 2006. 

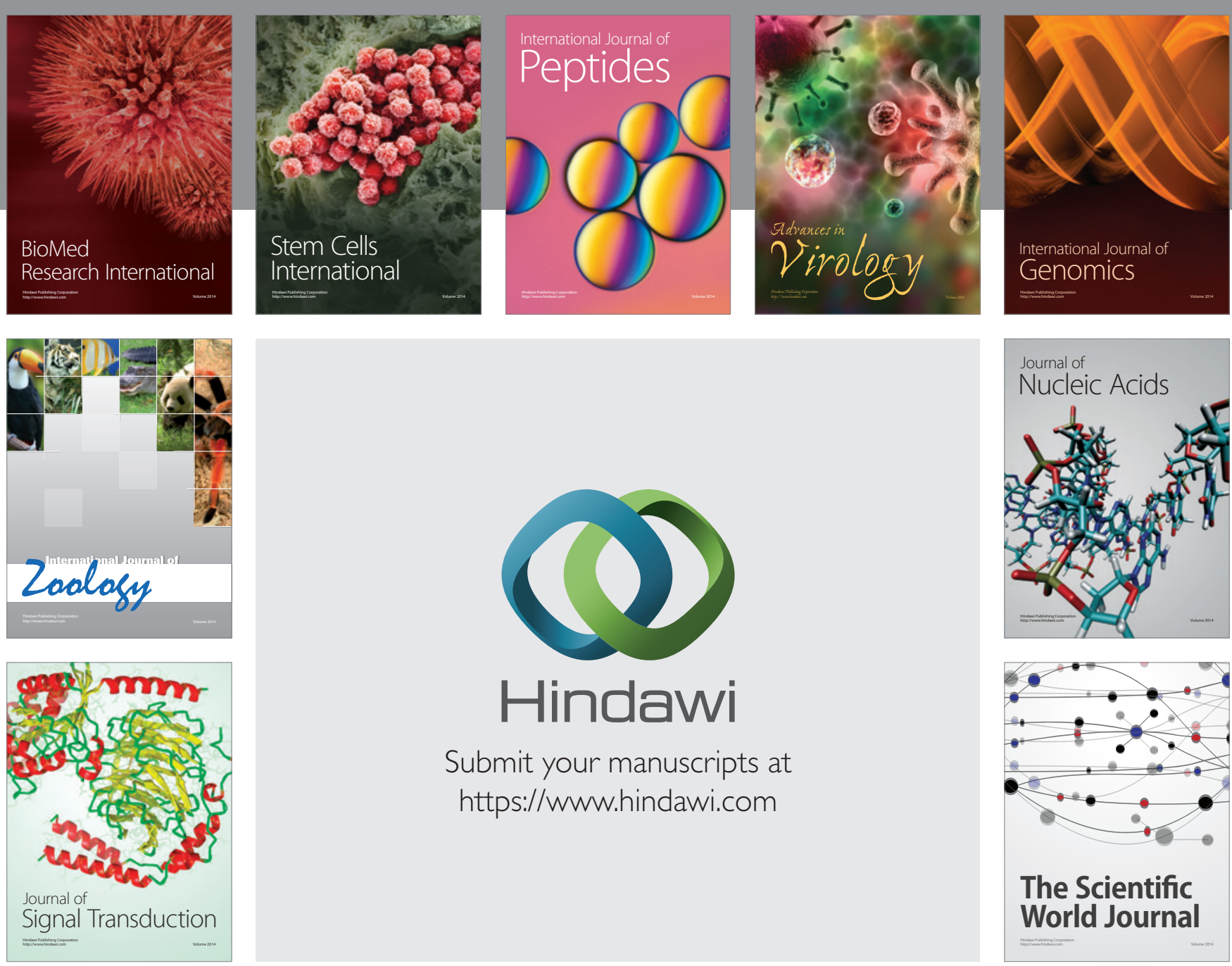

Submit your manuscripts at

https://www.hindawi.com
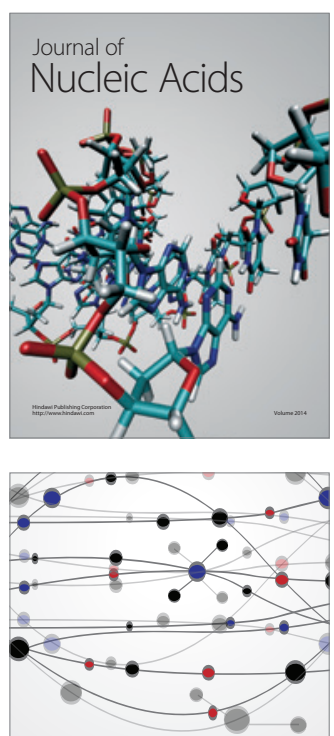

The Scientific World Journal
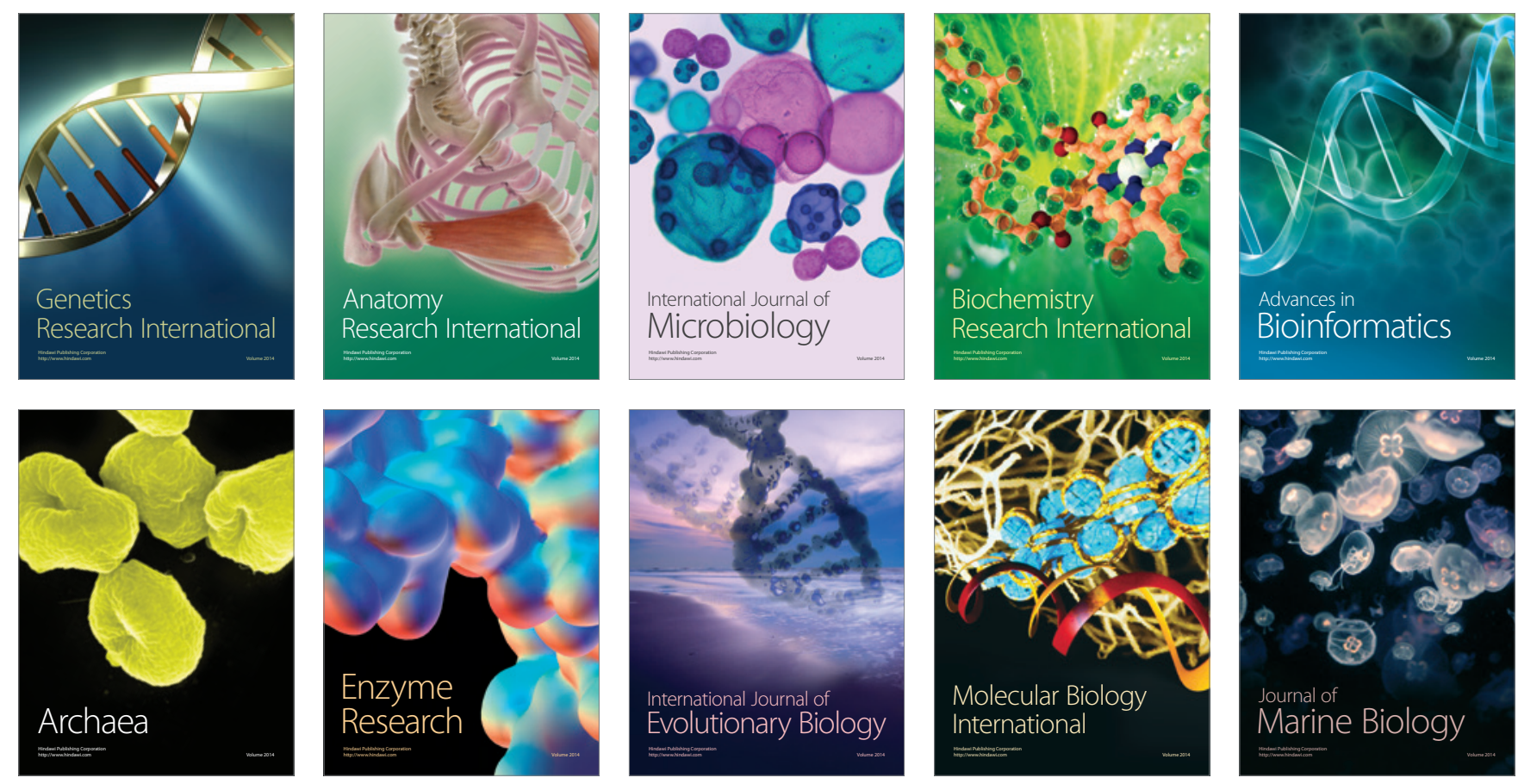